\title{
PENGETAHUAN, SIKAP, DAN PENGGUNAAN KACAMATA RENANG PADA KOMUNITAS SELAM DI KOLAM RENANG TAWANGALUN, BANYUWANGI
}

\author{
Hafida Yumna Huwaida, Retno Adriyani \\ Fakultas Kesehatan Masyarakat Universitas Airlangga \\ KNOWLEDGE, ATTITUDE, AND USING SWIMMING GOGGLES ON \\ DIVERS COMMUNITY IN TAWANGALUN SWIMMING POOL, BANYUWANGI
}

\begin{abstract}
Background: The water in swimming pools is filled with chemicals which causes the eyes irritation. Using goggles is the best way to protect swimmer eyes from all the chemicals in the swimming pool. This research aimed to analyze the relationship between knowledge and attitude with the use of swimming goggles by divers community members when they get practice at Tawangalun Swimming Pool, Banyuwangi.

Method:This is an analytical research with cross-sectional design.The population was children members of Divers Community as users of Tawangalun Swimming Pool, Banyuwangi. The sample was drawn through a simple random sampling procedure, with sample size were 30 respondents. Data collection were done by interviewing respondents using questionnaire. The data were analyzed with chi-square to get the relationship between knowledge and attitude with the use of swimming goggles $(\alpha<0.05)$.

Result: Research respondents were between 5-16 years old, 87\% had good knowledge and $80 \%$ had good attitude about using swimming goggles, $93 \%$ always wear swimming goggles while practicing in Tawangalun Swimming Pool, Banyuwangi. There was a significant correlation between knowledge with swimming goggles wear $(p=0.014)$, otherwise attitude with swimming goggles wear $(p=0.366)$.

Conclusion: Unhealthy behaviors such as not wearing swimming goggles can be frequently found in dive community as users of swimming pool. Public health prevention strategies should be implemented to improve awareness of swimming goggles wearing.
\end{abstract}

Keyword: Knowledge, attitude, use of swimming goggles, divers community

\begin{abstract}
ABSTRAK
Latar Belakang: Air kolam renang mengandung bahan kimia yang dapat menyebabkan iritasi mata. Penggunaan kacamata renang merupakan upaya pencegahan terbaik untuk melindungi mata para perenang dari bahan kimia pada air kolam renang. Penelitian ini bertujuan untuk menganalisis hubungan antara pengetahuan dan sikap dengan tindakan penggunaan kacamata renang pada anak anggota komunitas selam saat mereka berlatih di Kolam Renang Tawangalun, Banyuwangi.

Metode: Penelitian ini merupakan penelitian observasional dengan rancang bangun cross-sectional. Populasi penelitian ini adalah anak anggota Komunitas Selam sebagai pengguna Kolam Renang Tawangalun Banyuwangi. Sampel penelitian diperoleh menggunakan teknik simple random sampling, dengan besar sampel 30 responden. Pengumpulan data dilakukan dengan mewawancarai responden dengan menggunakan kuesioner. Data dianalisis secara analitik menggunakan uji statistik chi-square untuk mengetahui hubungan antara pengetahuan dan sikap dengan penggunaan kacamata renang $(\alpha<0,05)$.

Hasil Penelitian: Responden penelitian berumur antara 5-16 tahun. Data yang diperoleh menunjukkan bahwa $87 \%$ responden memiliki pengetahuan baik dan $80 \%$ responden bersikap baik terkait penggunaan kacamata renang, 93\% responden selalu menggunakan kacamata renang saat berlatih di Kolam Renang Tawangalun, Banyuwangi. Hasil uji statistik menunjukkan bahwa terdapat hubungan yang signifikan antara pengetahuan responden dengan penggunaan kacamata renang $(\mathrm{p}=0,014)$, sebaliknya antara sikap dan penggunaan kacamata renang tidak ada hubungan $(\mathrm{p}=0,366)$.

Kesimpulan: Perilaku tidak sehat, seperti tidak memakai kacamata renang masih sering ditemukan pada anggota komunitas selam sebagai pengguna kolam renang. Strategi pencegahan dalam bidang kesehatan masyarakat harus diterapkan untuk meningkatkan kesadaran penggunaan kacamata renang.
\end{abstract}

Kata kunci: Pengetahuan, sikap, penggunaan kacamata renang, komunitas selam 


\section{PENDAHULUAN}

Perilaku merupakan respon individu yang terjadi karena adanya stimulus atau rangsangan dari luar. Perilaku terdiri dari tiga domain, yaitu pengetahuan, sikap dan tindakan. Pengetahuan merupakan hasil suatu penginderaan individu terhadap suatu objek tertentu, sehingga individu tersebut menjadi tahu. Penginderaan tersebut terjadi melalui panca indera manusia, yakni indera penglihatan, pendengaran, penciuman, perasa, dan peraba. Sikap merupakan respon individu terhadap pemahaman atau penilaian suatu objek tertentu, dimana respon individu tersebut masih bersifat tertutup. Suatu sikap belum tentu terwujud dalam sebuah tindakan. Tindakan tersebut dapat terwujud karena adanya faktor pendukung atau suatu kondisi yang memungkinkan, seperti ketersediaan fasilitas dan sarana prasarana. ${ }^{1}$

Kacamata renang merupakan salah satu fasilitas pendukung untuk mencegah gangguan iritasi mata pada pengguna kolam renang. ${ }^{2}$ Penggunaan kacamata renang bertujuan untuk melihat dan memperjelas penglihatan atau pandangan pengguna kolam renang dalam air kolam renang. Selain itu, penggunaan kacamata renang dapat menghambat masuknya air ke dalam mata pengguna kolam renang. Kacamata renang yang digunakan harus kedap air, tidak berkabut, dan tidak berembun. ${ }^{3}$ Kacamata renang digunakan untuk keamanan dan perlindungan mata dari klorin di dalam air kolam renang. Namun penggunaan kacamata renang juga harus diperhatikan, karena penggunaan kacamata renang yang tidak sesuai dapat menyebabkan cidera di sekitar area mata. Selain itu, pemakaian kacamata renang yang tidak tepat dapat menyebabkan pandangan pengguna kolam renang menjadi terhalang. ${ }^{4}$ Ketersediaan kacamata renang dapat mendorong pengguna kolam renang untuk menerapkan penggunaan kacamata renang. Tindakan penggunaan kacamata renang kemungkinan dapat terjadi karena pengetahuan dan sikap pengguna kolam renang yang baik. Pengguna kolam renang yang tidak menggunakan kacamata renang memiliki risiko 4,717 kali mengalami keluhan iritasi mata dibandingkan pengguna kolam renang yang menggunakan kacamata renang. ${ }^{5}$

Iritasi mata merupakan salah satu gangguan kesehatan yang sering dialami oleh pengguna kolam renang. Iritasi mata merupakan istilah umum untuk menggambarkan sensasi yang mengganggu mata, seperti mata merah, mata pedih, mata kering, mata terasa gatal, mata terasa berair dan mata terasa berpasir. ${ }^{6}$ Penyebab iritasi mata pada pengguna kolam renang adalah kloramin, keseimbangan air kolam renang, gesekan air dengan kotoran pada kornea mata di kolam renang, dan faktor lingkungan. ${ }^{7}$

Klorinasi air kolam renang merupakan salah satu bentuk pengolahan air kolam renang yang bertujuan untuk mematikan mikroorganisme patogen dan mengoksidasi bahan-bahan kimia dalam air kolam renang dengan proses pemberian klorin dalam air. Senyawa klor yang umum digunakan adalah gas klor, senyawa hipoklorit, klor dioksida, bromide klorida, dihidroisosianurate, dan kloramin. $^{8} \quad$ Penggunaan klor sebagai desinfektan harus diperhatikan dengan baik dan disesuaikan dengan batas aman. Permenkes RI No. 32/MENKES/PER/V/2017 tentang Standar Baku Mutu Kesehatan Lingkungan dan Persyaratan Kesehatan Air untuk Keperluan Higiene Sanitasi, Kolam Renang, Solus per Aqua, dan Pemandian Umum menyatakan bahwa standar baku mutu sisa klor bebas pada kolam renang beratap atau tidak beratap adalah sebesar 1-1,5 mg/l, dan sisa klor terikat adalah sebesar $3 \mathrm{mg} / \mathrm{l}$ untuk semua jenis kolam renang. ${ }^{9}$ Konsentrasi sisa klor yang kurang dapat menyebabkan bakteri dalam kolam renang tidak terdesinfeksi secara optimal, sedangkan konsentrasi sisa klor yang berlebih dapat menimbulkan gangguan kesehatan karena kadar sisa klor 
yang tertinggal dalam kolam renang melebihi batas aman yang telah ditetapkan. ${ }^{10}$ Adapun gangguan kesehatan yang ditimbulkan akibat paparan klor yang berlebih adalah iritasi saluran nafas, sesak nafas, sakit tenggorokan, batuk, iritasi kulit, dan iritasi mata. ${ }^{11}$

Selain klor, penyebab terjadinya gangguan iritasi mata pada pengguna kolam renang adalah kebiasaan buang air kecil, buang ingus dan meludah di kolam renang, serta membilas badan di kolam renang dengan menggunakan sabun dan shampoo yang dapat mempengaruhi kandungan amonia dalam air kolam renang. ${ }^{12}$ Amonia dalam air kolam renang dapat menimbulkan masalah bau dan rasa. Iritasi mata karena amonia dapat terjadi karena amonia dalam air kolam renang bergabung dengan klor dan membentuk kloramin. Kloramin dalam air kolam renang terbentuk oleh klorin yang bereaksi dengan kontaminan yang mengandung nitrogen. ${ }^{13}$ Sumber peningkatan amonia dalam air kolam renang antara lain berasal dari pengguna kolam renang, yaitu urin, keringat, dan saliva pengguna kolam renang. ${ }^{14}$

Kolam Renang Tawangalun, Banyuwangi merupakan kolam renang prestasi yang dikelola oleh Dinas Pemuda dan Olahraga Kabupaten Banyuwangi. Kolam Renang ini dijadikan sebagai tempat untuk latihan renang dan olahraga air oleh klub renang dan klub olah raga air di Banyuwangi. Komunitas Selam adalah salah satu klub olah raga air yang rutin berlatih di Kolam Renang Tawangalun, Banyuwangi. Selain itu, kolam renang ini juga dijadikan sebagai tempat untuk belajar renang dan pengambilan nilai renang pelajar SLTP dan SLTA. Selain untuk kepentingan prestasi, kolam renang ini juga dijadikan sebagai tempat untuk rekreasi oleh masyarakat umum.

Tujuan dari penelitian ini adalah untuk mengetahui hubungan pengetahuan dan sikap terkait dengan penggunaan kacamata renang pada Komunitas Selam yang berlatih di Kolam Renang Tawangalun, Banyuwangi.

\section{METODE}

Penelitian ini merupakan penelitian analitik observasional dengan rancang bangun cross sectional. Penelitian ini dilakukan di Kolam Renang Tawangalun, Banyuwangi yang terletak di Kelurahan Mojopanggung, Kecamatan Giri, Kabupaten Banyuwangi. Penelitian ini dilakukan pada bulan April - Mei 2018.

Populasi pada penelitian ini adalah anak-anak yang merupakan anggota Komunitas Selam yang tergabung dalam POSSI (Persatuan Olahraga Selam Seluruh Indonesia) Kabupaten Banyuwangi. Komunitas Selam Banyuwangi ini secara rutin menggunakan kolam renang di Tawangalun untuk berlatih. Populasi penelitian ini sebesar 75 anak. Kriteria inklusi sampel penelitian ini adalah anggota Komunitas Selam Banyuwangi yang berada di lokasi penelitian, bersedia menjadi responden penelitian dan telah diijinkan oleh orang tuanya untuk ikut serta dalam penelitian ini, dapat berkomunikasi dengan baik, serta aktif berlatih di Kolam Renang Tawangalun, Banyuwangi. Penghitungan besar sampel menggunakan rumus Lemeshow, ${ }^{15}$ diperoleh besar sampel sebanyak 30 anak. Penentuan responden dilakukan menggunakan metode simple random sampling. Pengambilan sampel responden dilakukan dengan cara mengundi daftar hadir agar didapatkan sampel yang representatif.

Pengumpulan data dilakukan dengan mewawancarai responden dengan menggunakan kuesioner. Wawancara dilakukan oleh peneliti secara lisan, 
mengunakan bahasa sehari-hari yang mudah dimengerti oleh responden. Sebelum dilakukan wawancara, orang tua dan responden diberikan penjelasan mengenai penelitian. Penelitian ini telah lolos kaji etik penelitian oleh Komisi Etik Penelitian Kesehatan (KEPK) Fakultas Kesehatan Masyarakat Universitas Airlangga. Pengolahan data pengetahuan, sikap, dan penggunaan kacamata renang dinilai dan kemudian dikelompokkan menjadi data ordinal. Teknik analisis data dilakukan secara deskriptif dan analitik. Analisis deskriptif dilakukan dengan menyajikan data dalam bentuk tabel distribusi frekuensi dan narasi dari masing-masing variabel yang diamati. Sedangkan analisis analitik dilakukan menggunakan uji Chi square untuk mengetahui hubungan antara variabel independen dengan variabel dependen yang diamati.

\section{HASIL PENELITIAN Karakteristik Responden}

Karakteristik responden penelitian yang merupakan anggota Komunitas Selam yang berlatih di Kolam Renang Tawangalun, Banyuwangi adalah sebagai berikut:

Tabel 1.

Karakteristik Reponden Anggota Komunitas Selam Banyuwangi

\begin{tabular}{lcc}
\hline \multicolumn{1}{c}{ Variabel } & Frekuensi & Persentase (\%) \\
\hline Umur (Tahun) & & \\
$5-8$ & 8 & 27 \\
$9-12$ & 16 & 53 \\
$13-16$ & 6 & 20 \\
Jenis Kelamin & & \\
Laki-laki & 13 & 43 \\
Perempuan & 17 & 57 \\
\hline
\end{tabular}

Reponden penelitian memiliki umur antara 5 sampai dengan 16 tahun. Berdasarkan Tabel 1, sebagian besar umur responden berada pada rentang umur $9-12$ tahun, yaitu sebanyak 16 anak (53\%). Jenis kelamin reponden sebagian besar adalah perempuan, yaitu sebanyak 17 anak (57\%). Setiap berlatih, seluruh responden diharuskan untuk selalu membawa kacamata renang oleh pelatih mereka.

\section{Pengetahuan Anggota Komunitas Selam}

Pada penelitian ini, diteliti mengenai pengetahuan responden terkait penyebab dan pencegahan terjadinya gangguan iritasi mata di kolam renang. Distribusi frekuensi pengetahuan responden adalah sebagai berikut:

Tabel 2.

Pengetahuan Responden Anggota Komunitas Selam Banyuwangi

\begin{tabular}{lcc}
\hline \multicolumn{1}{c}{ Kategori } & Frekuensi & Persentasi (\%) \\
\hline Baik & 26 & 87 \\
Buruk & 4 & 13 \\
\hline Total & $\mathbf{3 0}$ & $\mathbf{1 0 0}$ \\
\hline
\end{tabular}

Tabel 2. menunjukkan bahwa responden memiliki pengetahuan yang baik, yaitu $87 \%$. Sebanyak $16 \%$ responden tidak mengetahui bahwa iritasi mata dapat terjadi karena adanya bahan kimia yang ada dalam air kolam renang dan hanya $10 \%$ responden yang tidak mengetahui bahwa dengan menggunakan kacamata renang, iritasi mata karena berenang dapat dicegah.

\section{Sikap Anggota Komunitas Selam}

Sikap yang diteliti dalam penelitian ini adalah tanggapan responden terhadap pemahaman atau penilaian terkait penyebab dan pencegahan gangguan iritasi mata di kolam renang. Distribusi frekuensi sikap responden dicantumkan pada

Tabel 3 berikut ini: 
Tabel 3.

Sikap Responden Anggota Komunitas Selam Banyuwangi

\begin{tabular}{lcc}
\hline \multicolumn{1}{c}{ Kategori } & Frekuensi & Persentasi (\%) \\
\hline Baik & 24 & 80 \\
Buruk & 6 & 20 \\
\hline Total & $\mathbf{3 0}$ & $\mathbf{1 0 0}$ \\
\hline
\end{tabular}

Tabel 3 menunjukkan bahwa $80 \%$ anggota Komunitas Selam, Banyuwangi memiliki sikap yang baik. Semua responden memiliki sikap setuju untuk menggunakan kacamata renang saat berlatih di Kolam Renang Tawangalun, Banyuwangi. Namun, sebanyak $28 \%$ responden tidak memiliki sikap setuju dengan penyebab peningkatan bahan kimia dalam air kolam renang.

Penggunaan Kacamata Renang pada Komunitas Selam

Penggunaan kacamata renang merupakan istilah yang digunakan untuk menggambarkan bahwa pengguna kolam renang selalu menggunakan kacamata renang saat melakukan aktivitas di kolam renang. Distribusi penggunaan kacamata renang pada anggota Komunitas Selam Banyuwangi adalah sebagai berikut:

Tabel 4.

Penggunaan Kacamata Renang pada Anggota Komunitas Selam Banyuwangi

\begin{tabular}{ccc}
\hline Kategori & Frekuensi & Persentasi $(\boldsymbol{\%})$ \\
\hline Ya & 28 & 93 \\
Tidak & 2 & 7 \\
\hline Total & $\mathbf{3 0}$ & $\mathbf{1 0 0}$ \\
\hline
\end{tabular}

Berdasarkan Tabel 4, sebanyak 93\% anggota Komunitas Selam Banyuwangi selalu menggunakan kacamata renang saat berlatih di Kolam Renang Tawangalun, Banyuwangi. Selebihnya, responden yang tidak selalu menggunakan kacamata renangnya $(7 \%)$.

Hubungan Pengetahuan dengan Penggunaan Kacamata Renang pada Anggota Komunitas Selam

Tabulasi silang antara pengetahuan dengan penggunaan kacamata renang pada anggota KomunitasSelam Banyuwangi adalah sebagai berikut:

Tabel 5.

Tabulasi Silang antara Pengetahuan dengan Penggunan Kacamata Renang pada Anggota Komunitas Selam Banyuwangi

\begin{tabular}{|c|c|c|c|c|c|c|}
\hline \multirow{3}{*}{ Pengetahuan } & \multicolumn{4}{|c|}{$\begin{array}{c}\text { Penggunaan } \\
\text { Kacamata Renang }\end{array}$} & \multirow{2}{*}{\multicolumn{2}{|c|}{ Total }} \\
\hline & \multicolumn{2}{|c|}{ Ya } & \multicolumn{2}{|c|}{ Tidak } & & \\
\hline & $\mathbf{n}$ & $\%$ & $\mathbf{n}$ & $\%$ & $\mathbf{n}$ & $\%$ \\
\hline Baik & 26 & 87 & 0 & 0 & 26 & 87 \\
\hline Buruk & 2 & 6 & 2 & 7 & 4 & 13 \\
\hline \multicolumn{7}{|c|}{$\mathrm{p}=0,014$} \\
\hline
\end{tabular}

Berdasarkan Tabel 5, menunjukkan bahwa sebagian besar anggota Komunitas Selam Banyuwangi yang mempunyai pengetahuan baik selalu menggunakan kacamata renang (87\%). Hasil uji statistik menunjukkan bahwa nilai $\mathrm{p}=0,014<\alpha$ $(0,05)$, artinya ada hubungan signifikan antara pengetahuan dengan penggunaan kacamata renang pada anggota Komunitas Selam Banyuwangi.

Hubungan Sikap dengan Penggunaan Kacamata Renang pada Komunitas Selam

Tabulasi silang antara sikap dengan penggunaan kacamata renang pada anggota 
Komunitas Selam Banyuwangi adalah sebagai berikut:

Tabel 6.

Tabulasi Silang antara Sikap dengan

Penggunan Kacamata Renang pada Anggota Komunitas Selam Banyuwangi

\begin{tabular}{|c|c|c|c|c|c|c|}
\hline \multirow{3}{*}{ Sikap } & \multicolumn{4}{|c|}{$\begin{array}{c}\text { Penggunaan } \\
\text { Kacamata Renang }\end{array}$} & \multirow{2}{*}{\multicolumn{2}{|c|}{ Total }} \\
\hline & \multicolumn{2}{|c|}{ Ya } & \multicolumn{2}{|c|}{ Tidak } & & \\
\hline & n & $\%$ & n & $\%$ & n & $\%$ \\
\hline Baik & 23 & 77 & 1 & 3 & 24 & 80 \\
\hline Buruk & 5 & 17 & 1 & 3 & 6 & 20 \\
\hline
\end{tabular}

Tabel 6 menunjukkan bahwa anggota Komunitas Selam Banyuwangi sebagian besar mempunyai yang memiliki sikap baik selalu menggunakan kacamata renang (77\%). Hasil uji statistik menunjukkan bahwa nilai $\mathrm{p}$ $=0,366>\alpha(0,05)$, artinya tidak ada hubungan yang signifikan antara sikap dengan penggunaan kacamata renang pada anggota Komunitas Selam Banyuwangi.

\section{PEMBAHASAN}

\section{Pengetahuan Komunitas Selam}

Pengetahuan merupakan hasil dari tahu, dan ini terjadi setelah orang melakukan penginderaan terhadap suatu objek tertentu. ${ }^{1}$ Pengetahuan dapat diperoleh dari pengalaman sendiri atau pengalaman orang lain. ${ }^{16}$ Hasil penelitian menunjukkan bahwa sebagian besar anggota Komunitas Selam Banyuwangi memiliki pengetahuan yang baik (87\%) mengenai penyebab dan pencegahan terjadinya iritasi mata saat berenang. Penelitian sejenis juga sejalan dengan hasil penelitian ini, dimana sebagian besar pengguna kolam renang renang di Sidoarjo memiliki pengetahuan yang baik $(76,7 \%){ }^{17}$
Hasil uji statistik menunjukkan bahwa terdapat hubungan signifikan antara pengetahuan dengan penggunaan kacamata renang pada Komunitas Selam Banyuwangi. Hal ini menunjukkan bahwa pengguna kolam renang yang mempunyai pengetahuan baikmerupakan faktor pemungkin bagi anggota Komunitas Selam Banyuwangi untuk selalu menggunakan APD berupa kacamata renang saat melakukan aktivitas di kolam renang. Pada penelitian mengenai keluhan iritasi mata pengguna kolam renang Tirta Wisata di Kabupaten Jombang, disebutkan bahwa iritasi mata pada pengguna kolam renang dapat terjadi karena tidak menggunakan Alat Pelindung Diri (APD) berupa kacamata renang. ${ }^{18}$ Terkait dengan penggunaan APD, penelitian lain juga menyatakan ada hubungan signifikan antara pengetahuan responden dengan penggunaan APD. Penelitian tersebut menjelaskan, pengetahuan yang baik akan memberikan kontribusi yang tinggi terhadap penggunaan APD. ${ }^{19}$ Namun, penelitian lain menyatakan hal yang sebaliknya, yaitu tidak ada hubungan antara pengetahuan dengan kesadaran perilaku pencegahan risiko kesehatan di kolam renang. Dalam penelitian ini dijelaskan bahwa informasi tertulis maupun secara lisan dapat meningkatkan pengetahuan, tetapi belum cukup mengubah perilaku pengguna kolam renang untuk melakukan upaya pencegahan di kolam renang. ${ }^{22}$

Tingkatan pengetahuan meliputi tahu, memahami, aplikasi, analisis, sintesa, dan evaluasi. ${ }^{1}$ Berdasarkan teori tersebut dapat diketahui bahwa tingkatan pengetahuan anggota Komunitas Selam Banyuwangi telah berada pada tingkatan aplikasi, yaitu mampu menerapkan atau mengaplikasikan pengetahuan yang dimiliki. Itu artinya, sebagian besar anggota Komunitas Selam Banyuwangi mampu menerapkan pengetahuan yang dimiliki terkait penyebab dan pencegahan gangguan iritasi mata, sehingga sebagian besar selalu menggunakan 
kacamata renang untuk mencegah gangguan iritasi mata akibat aktivitas di kolam renang.

Pengetahuan merupakan ingatan mengenai suatu hal yang diketahui dengan baik melalui belajar, pengalaman, maupun informasi yang diperoleh dari orang lain. Informasi tersebut dapat diperoleh melalui sekolah, komunitas olahraga air, dan pengelola kolam renang. Selain itu, internet dan media sosial juga dapat memberikan informasi terkait penyebab dan pencegahan gangguan iritasi mata akibat aktivitas di kolam renang. ${ }^{12}$

Faktor yang mempengaruhi pengetahuan seseorang adalah pendidikan, pengalaman, usia, sosial budaya, dan lingkungan. ${ }^{21}$ Berdasarkan teori tersebut, faktor yang mempengaruhi pengetahuan anggota Komunitas Selam adalah pendidikan yang diperoleh melalui pendidikan formal atau sekolah dan pendidikan informal tempat berlatih selam. Pengalaman dalam memperoleh kebenaran suatu pengetahuan dapat diperoleh di tempat berlatih selam. Usia yang mempengaruhi daya tangkap dan pola pikir anggota Komunitas Selam. Kondisi sosial budaya dan lingkungan tempat berlatih selam juga dapat menambah pengetahuan anggota Komunitas Selam dalam hal penggunaan kaca mata renang sebagai salah satu upaya pencegahan iritasi mata saat berenang. Sehingga pemberian informasi mengenai pentingnya menggunakan kacamata renang dapat dilakukan dengan berbagai jalur yaitu melalui pendidikan formal, kelompok Komunitas Selam, dan tempat berlatih selam, dalam penelitian ini tempat berlatih responden adalah di Kolam Renang Tawangalun, Banyuwangi.

\section{Sikap Anggota Komunitas Selam}

Sikap merupakan respon individu terhadap pemahaman atau penilaian suatu objek tertentu, dimana respon individu tersebut masih bersifat tertutup. ${ }^{1}$ Hasil penelitian menunjukkan bahwa sebagian besar (80\%) anggota Komunitas Selam Banyuwangi memiliki sikap yang baik. Sebagian besar anggota Komunitas Selam Banyuwangi memiliki pendapat atau penilaian yang baik mengenai penyebab dan pencegahan gangguan iritasi mata pada pengguna kolam renang. Hal ini berbeda dengan penelitian sejenis, dimana hasilnya menunjukkan bahwa pengguna kolam renang di Sidoarjo memiliki sikap yang kurang, yaitu sebesar $40 \% .^{17}$

Namun demikian, berdasar hasil uji statistik menunjukkan bahwa tidak ada hubungan yang bermakna antara sikap dengan penggunaan kacamata renang pada anggota Komunitas Selam Banyuwangi. Pengguna kolam renang yang mempunyai sikap baik belum tentu selalu menggunakan APD berupa kacamata renang saat melakukan aktivitas di kolam renang. Hal ini sejalan dengan penelitian lain yang menyatakan bahwa tidak ada hubungan signifikan antara sikap responden dengan penggunaan APD. Hal ini dapat disebabkan karena adanya berbagai faktor yang mempengaruhi sikap seseorang selain pengetahuan. Responden yang memiliki sikap positif tetapi tidak menggunakan APD dapat disebabkan karena kurangnya niat sehingga mudah terpengaruh dengan lingkungan yang terbiasa tidak menggunakan APD, kurangnya motivasi dalam menggunakan APD, serta adanya perasaan responden yang merasa sudah terbiasa dengan lingkungan tersebut. ${ }^{19}$

Sikap merupakan kecenderungan untuk melakukan suatu tindakan. Sikap belum tentu terwujud dalam suatu tindakan. Setelah individu memperoleh stimulus atau rangsangan, kemudian melakukan penilaian atau pendapat terhadap suatu hal maka yang diharapkan adalah terbentuknya suatu tindakan. ${ }^{22}$ Terdapat sikap beberapa anggota Komunitas Selam Banyuwangi yang tidak terwujud dalam tindakan penggunaan kacamata renang. Meskipun telah tersedia kacamata renang, namun hal tersebut tidak 
membuat mereka sadar dan mau untuk selalu menggunakan kacamata renang saat melakukan aktivitas di kolam renang.

Manifestasi sikap tidak dapat langsung dilihat, tetapi hanya ditafsirkan terlebih dahulu dari perilaku yang tertutup. ${ }^{23}$ Terdapat empat tingkatan sikap, yaitu menerima, merespon, menghargai dan bertanggung jawab. ${ }^{1}$ Berdasarkan teori tersebut dapat diketahui bahwa tingkatan sikap anggota Komunitas Selam Banyuwangi belum semuanya berada pada tingkatan merespon, tetapi ada juga yag masih dalam tingkatan menerima yaitu menyetujui suatu hal tetapi tidak melakukan respon terhadap hal tersebut. Itu artinya, anggota Komunitas Selam Banyuwangi menyetujui faktor penyebab dan pencegahan gangguan iritasi mata, tetapi tidak melakukan tindakan pencegahan untuk memperkecil risiko gangguan iritasi mata di kolam renang. ${ }^{12}$

Sikap seseorang dapat dipengaruhi oleh lingkungan, pengalaman, dan pendidikan. ${ }^{24}$ Berdasarkan teori tersebut, sikap anggota Komunitas Selam dalam melakukan tindakan pencegahan gangguan iritasi mata di kolam renang dapat dipengaruhi oleh lingkungan tempat berlatih, pengalaman yang diperoleh selama berlatih, dan pendidikan yang diberikan oleh pelatih. Lingkungan tempat berlatih dapat membentuk kepribadian anggota Komunitas Selam. Lingkungan tersebut merupakan segala sesuatu yang digunakan dalam proses pembelajaran yang meliputi kondisi, keadaan, maupun fasilitas yang ada di lingkungan tersebut. ${ }^{25}$ Pengalaman selama

\section{DAFTAR PUSTAKA}

1. Notoatmodjo, S. Promosi Kesehatan dan Perilaku Kesehatan. Jakarta: PT. Rineka Cipta. 2012.

2. American Academy of Ophtalmology. What you should know about swimming and your eyes. American Academy of Ophtalmology, San Fransisco. 2016. Tersedia di: berlatih mempengaruhi sikap anggota Komunitas Selam karena anggota tersebut pernah mengalami dan pernah melihat orang lain melakukan suatu tindakan pencegahan di kolam renang. Pendidikan dapat mempengaruhi pembentukan sikap dan faktor berpengaruh yang ditentukan oleh kepribadian, intelegensia, dan minat. ${ }^{26}$

\section{KESIMPULAN DAN SARAN}

Karakteristik anggota Komunitas Selam Banyuwangi sebagian besar berumur 9-12 tahun, dan berjenis kelamin perempuan (57\%). Anggota Komunitas Selam Banyuwangi memiliki pengetahuan yang baik (87\%), sikap yang baik $(80 \%)$, dan selalu mengggunakan kacamata renang (93\%). Terdapat hubungan yang bermakna antara pengetahuan dengan penggunaan kacamata renang. Namun tidak terdapat hubungan yang bermakna antara sikap dengan penggunaan kacamata renang.

Saran dari penelitian ini adalah pengguna kolam renang sebaiknya selalu menggunakan kacamata renang untuk memperkecil risiko gangguan iritasi mata akibat aktivitas di kolam renang. Selain itu, perlu dilakukan penyegaran mengenai penyebab dan pencegahan gangguan kesehatan di kolam renang yang dapat dilakukan oleh pelatih ataupun senior pada komunitas renang atau selam. Pengelola kolam renang dapat memberikan himbauan berupa informasi tertulis mengenai penggunaan dan pemakaian kacamata renang yang benar pada pengguna kolam renang.

https://www.aao.org. [Diakses 23 November 2017].

3. Teberik, K., Karacabey, K., Saglam, H., Ozbar, N., Karadenizli, I., Ozmendiverli, R., dan Kaya, M. The Effects of Swimming Goggles on Intraocular Pressure in Children. Studies on Ethno-Medicine, vol. 9, no. 3. 2015. 
4. Irish Water Safety's. Irish Water Safety's School Swimming Guidelines. Irish Water Safety's, Ireland.2010. Tersedia di https://www.iws.ie. [Diakses 23 November 2017]

5. Dewi, S M. Hubungan Kualitas Air Kolam Renang dengan Keluhan Iritasi Mata pada Pengguna Kolam Renang Teratai Kota Padang. [Skripsi]. Padang: Universitas Andalas. 2017.

6. American Academy of Opthalmology. Irritation. American Academy of Opthalmology, San Francisco. 2015. Tersedia di: https://www.aao.org. [Diakses 23 November 2017].

7. Osinski, A. Effects of pool water an swimmers' eyes, ears, teeth and hair. Aquatic Consulting Services, California. 1987. Tersedia di: http://www.alisonosinski.com. [Diakses 23 November 2017].

8. Chandra, B. Pengantar Kesehatan Lingkungan. Jakarta: Penerbit Buku Kedokteran EGC. 2005.

9. Peraturan Menteri Kesehatan Republik Indonesia Nomor 32 tahun 2017 tentang Standar Baku Mutu Kesehatan Lingkungan dan Persayaratan Kesehatan Air untuk Keperluan Higiene Sanitasi, Kolam Renang, Solus per Aqua, dan Pemandian Umum. Kementrian Kesehatan Republik Indonesia. Jakarta. 2017

10. Cita, D W. dan Adriyani, R. Kualitas Air dan Keluhan Kesehatan Pengguna Kolam Renang di Sidoarjo. Jurnal Kesehatan Lingkungan, vol. 7, no. 1:26-31. 2013.

11. New York State Department of Health. The Facts about Chlorine. Department of Health, New York. 2004.

12. Huwaida, $\mathrm{H}$ Y. Analisis Faktor Predisposing, Enabling, dan Reinforcing Gangguan Iritasi Mata pada Komunitas Selam Pengguna Kolam Renang GOR Tawangalun Banyuwangi. [Skripsi]. Banyuwangi: Universitas Airlangga. 2018.

13. Wojtowicz, J A. Chemistry of Nitrogen Compounds in Swimming Pool Water. Journal of the Swimming Pool and Spa Industry, vol. 4, no: 1:30-40. 2001.

14. Puspitasari, N K. Analisis Frekuensi Mikronukleus pada Sel Epitel Mukosa
Bukal Rongga Mulut Atlet Renang di Yogyakarta. [Skripsi]. Yogyakarta: Universitas Gadjah Mada. 2016.

15. Lemeshow, S. Hosmer, D W., Klar, J., dan Lwanga, S K. Adequacy of Sample Size in Health Studies. England: John Wiley \& Sons. 1990.

16. Sari, I P. Hanim, M. dan Febry, F. Pengeahuan, Sikap, dan Perilaku Ibu Rumah Tangga dalam Penggunaan Minyak Goreng Sawit di Kelurahan Indralaya Indah. Jurnal Ilmu Kesehatan Masyarakat, vo. 1, no. 2: 114-120. 2010.

17. Yuliandari, A R. Kualitas Air Kolam Renang dan Perilaku Pengguna Kolam Renang serta Gangguan Iritasi Kulit dan Iritasi Mata di Sidoarjo. [Skripsi]. Surabaya: Universitas Airlangga. 2016.

18. Arimbawati, N L Y D. Kualitas Air dan Keluhan Iritasi Mata pada Penguna Kolam Renang Tirta Wisata Kabupaten Jombang. [Skripsi]. Surabaya: Universitas Airlangga. 2013.

19. Situmorag, K. Hasyim, H. dan Sitprus, R J. Faktor-faktor yang Berhubungan dengan Penggunaan Alat Pelindung Diri (APD) pada Pekerja di Bagian Pengantongan dan Penyimpanan Urea (PPU) 3/4 PT. PUSRI Palembang. Jurnal Ilmu Kesehatan Masyarakat, vol. 1, no. 2: 92-96. 2010.

20. Galle, F., Dallolio, L., Marotta, M., Raqqi, A., Di Onofrio V., Liquori, G., Toni F., dan Leoni, E. Health Related Behaviors in Swimming Pool Users: Influence of Knowledge of Regulations and Awareness of Health Risk. International Journal of Environmental Research and Public Health, vol. 13, 513. doi:10.3390/ijerph13050513. 2016.

21. Firiani, N L. dan Andriyani, S. Hubungan antara Pengetahuan dengan Sikap Anak Usia Sekolah Akhir (10-12 Tahun) tentang Makanan Jajanan di SD Negeri II Tagog Apu Padalarang Kabupaten Bandung Barat Tahun 2015. Jurnal Pendidikan Keperawatan Indonesia, vol. 1, no. 1. 2015.

22. Notoatmodjo, S. Promosi Kesehatan: Teori dan Aplikasi. Jakarta: PT. Rineka Cipta. 2005. 
23. Fajar, N A. dan Misnaniarti. Faktor Determinan Perilaku Hidup Bersih dan Sehat pada Masyarakat Sungai Rambutan Kecamatan Indralaya Utara. Jurnal Ilmu Kesehatan Masyarakat, vol. 3, no. 2: 127-135. 2012.

24. Azwar, S. Sikap Manusia: Teori dan Pengukurannya. Yogyakarta: Pustaka Pelajar. 2013.
25. Triyogo, H. Pengaruh Lingkungan Belajar dan Karakter terhadap Hasil Belajar Siswa Kelas XI Kompetensi Keahlian TKJ Di SMK Muhammadiyah 1 Playen. [Skripsi]. Yogyakarta: Universitas Negeri Yogyakarta. 2014.

26. Widayatun, T R. Ilmu Perilaku. Jakarta: CV. Agung Seto.2009. 